Research Article

\title{
In-vitro anti-oxidant studies on ethanolic extract of Alpinia galanga linn
}

\author{
Subash K. R.*, Bhanu Prakash G.
}

Department of Pharmacology, SVIMS-Sri Padmavathi Medical College for Women, SVIMS University, Tirupati, Andhra Pradesh, India

Received: 24 May 2016

Accepted: 07 June 2016

*Correspondence to:

Dr. Subash K.R.,

Email: subbu2207@yahoo.com

Copyright: (C) the author(s), publisher and licensee Medip Academy. This is an openaccess article distributed under the terms of the Creative Commons Attribution NonCommercial License, which permits unrestricted noncommercial use, distribution, and reproduction in any medium, provided the original work is properly cited.

\begin{abstract}
Background: The free radical scavenging activity by in-vitro antioxidant assay is performed on ethanolic extract of Alpinia galanga. Free radicals are highly reactive molecules produced as a by-product during metabolism of oxygen. From the current understanding of pathophysiology, it is extensively proved about the positive role of reactive oxygen species in degenerative disease. Nature has provided abundant fruits, vegetables and medicinal plants with rich source of antioxidants as the natural defense against free radical induced damage to living organisms.

Methods: The present study is to screen and document the antioxidant property of Alpinia galanga from Zingiberaceae family by lipid peroxidation, nitric oxide and 1,1-diphenyl-2-picrylhydrazil radical scavenging in vitro antioxidant assay.

Results: The results are the percentage inhibitory concentration (IC) of Alpinia galanga are as follows $\mathrm{IC}_{50} 102.70 \mathrm{mcg} / \mathrm{ml}, \mathrm{IC}_{50} 63.35 \mathrm{mcg} / \mathrm{ml}$ and $\mathrm{IC}_{50}$ $8.80 \mathrm{mcg} / \mathrm{ml}$ and for control vitamin $\mathrm{E}$ is $\mathrm{IC}_{50} 29 \mathrm{mcg} / \mathrm{ml}, \mathrm{IC}_{50} 15 \mathrm{mcg} / \mathrm{ml}$ and $\mathrm{IC}_{50} 18 \mathrm{mcg} / \mathrm{ml}$ by Lipid peroxidation, 1,1-diphenyl-2-picrylhydrazil and nitric oxide free radical scavenging activity respectively.

Conclusions: The Alpinia galanga root ethanolic extracts from Zingiberaceae family has significant nitric oxide free radical scavenging activity.
\end{abstract}

Keywords: Antioxidant assays, Nitric oxide, Free radicals, Alpinia galanga, Vitamin E

\section{INTRODUCTION}

A better understanding of pathophysiology from experimental and clinical studies has proven that oxidative stress by free radicals plays a major role in the pathogenesis of much degenerative disease. The imbalance between the generation of free radicals and antioxidant defense capacity by the organisms is leading to ageing and disease. ${ }^{1}$ Antioxidants prevents the oxidation of other chemicals and protect the cellular functions and organelles by neutralizing free radicals, which are natural by-products of cell metabolism and thereby preventing the deleterious effects. ${ }^{2,3}$ Free radicals are highly reactive with proteins, lipids, carbohydrates and DNA. The free radicals disturb the molecular arrangement of nearby stable molecules leading to stealing its electron. When the molecule loses its electron, again a free radical is formed, leading to a chain reaction resulting in the destruction of a cell. ${ }^{4}$
The source of free radicals in the living organism is both endogenous and exogenous which includes nutrient metabolism, ageing process etc. and tobacco smoke, ionizing radiation, air pollution, organic solvents, pesticides, etc. respectively. ${ }^{5}$ Endogenously antioxidant enzymes such as superoxide dismutase, catalase and glutathione peroxidase play important roles to counteract as a defense mechanism to fight against free radicals to maintain the redox homeostasis of cell and preventing cell injury. ${ }^{6}$ Similarly exogenously it's well known that vitamin $\mathrm{C}$ and $\mathrm{E}$ inhibit lipid peroxidation in cell. Hence in certain conditions the living organism is mostly dependent on exogenous rich source anti-oxidant to counteract the imbalance in the body anti-oxidant and reactive oxygen species. The World Health Organization recorded eighty percentage of world population is dependent on medicinal plants as primary health care in the form of plant extracts or their active components. ${ }^{7}$ 
The present study is an attempt to study on Alpinia galanga root from Zingiberaceae family with a focus on new group of bioactive activity (anti-oxidant), which might have protective effects against cell oxidation. This was done by standardized novel in vitro assays such as Lipid peroxidation, nitric oxide and 1,1-diphenyl-2-picrylhydrazil radical scavenging techniques.

\section{METHODS}

The Alpinia galanga plant rhizome was collected from herbal medicine raw material supplier and the same was authenticated by Siddha central research institute, Chennai, India. The rhizome extract as dry powder is obtained from chemiloids, Vijayawada, India. The extract was subjected to acute toxicity test followed by in vitro lipid peroxidation, nitric oxide and 1,1-diphenyl-2picrylhydrazil assays.

\section{In vitro lipid peroxidation assay ${ }^{8}$}

The chicken liver was obtained freshly from the local meat shop and a $10 \%$ liver homogenate was prepared with protein content adjusted to $500 \mathrm{~g} / \mathrm{ml}$ in the control containing $1 \mathrm{ml}$ of tissue homogenate, lipid peroxidation was initiated by adding a mixture of $\mathrm{FeSO}_{4}(25 \mathrm{mM}), \mathrm{KH}_{2} \mathrm{PO}_{4}(10 \mathrm{mM})$ and ascorbate (100 $\mathrm{mM})$ with total volume made up to $3 \mathrm{ml}$. The control containing mixture was incubated at $37{ }^{0} \mathrm{C}$ for 30 minutes. Similarly the test with mixture of different concentrations of Alpinia galanga extract ( 1.5 to $1000 \mathrm{mcg} / \mathrm{ml}$ ) was incubated. Thiobarbituric acid reactive substance levels are measured by spectrophotometer at an absorbance of $532 \mathrm{~nm}$ to find the extent of lipid peroxidation. ${ }^{9}$ By using the formula (\%) Inhibition=[(control-test $) /$ control $] / 100$ the percentage inhibition of lipid peroxidation is calculated.

\section{Nitric oxide free radical scavenging activity ${ }^{10}$}

The Alpinia galanga extract in different concentration (1.5 to $1000 \mathrm{mcg} / \mathrm{ml}$ ) was dissolved in methanol and sodium nitroprusside $(5 \mathrm{mM})$ in phosphate buffered saline. The solution total volume made up to $3 \mathrm{ml}$ and incubated at $25^{\circ} \mathrm{C}$ for 150 minutes. Each concentration was exposed to Greiss reagent and the absorbance of chromophore was read at $546 \mathrm{~nm}$. The control blank contained solvent without extract. The nitric oxide scavenging activity was calculated by the formula

$(\%)$ NO Scavenged $=[($ control-test $) /$ control $)] / 100$

\section{1-Diphenyl-2-picrylhydrazil radical scavenging assay $(\mathrm{DPPH})^{I I}$}

The Alpinia galanga extract of various concentrations (1.5 to $1000 \mathrm{mcg} / \mathrm{ml}$ ) was vortex mixed with 10 microliter DPPH in ethanol solution and incubated for 20 minutes at $37{ }^{\circ} \mathrm{C}$. The control blank contained solvent without extract. The absorbance of test mixture was measured at $517 \mathrm{~nm}$ and the percentage inhibition was calculated as the concentration of Alpinia galanga test mixture that gave $50 \%$ reduction in absorbance from control blank.

Vitamin $\mathrm{E}$ was used as positive control for all in vitro assay techniques.

\section{Statistical analysis}

The in-vitro assay techniques were performed in triplicates and the $\mathrm{IC}_{50}$ values are calculated by linear regression analysis Masterplex 2011 software.

\section{RESULTS}

The in-vitro assays done on Alpinia galanga on various concentrations ranging from 1.5 to $1000 \mathrm{mcg} / \mathrm{ml}$ in geometric progression and the $\mathrm{IC}_{50}$ values are determined by linear regression analysis. The free radical scavenging activity of Alpinia galanga and Vit $\mathrm{E}$ by lipid peroxidation is $102.70 \mathrm{mcg} / \mathrm{ml}$ and $29.70 \mathrm{mcg} / \mathrm{ml}$ respectively.

Table 1: In-vitro anti-oxidant assay.

\begin{tabular}{|lll|}
\hline Method & Vitamin-E IC $_{50}$ & Alpinia galanga $\mathrm{IC}_{50}$ \\
\hline LPO & $29 \mathrm{mcg} / \mathrm{ml}$ & $102.70 \mathrm{mcg} / \mathrm{ml}$ \\
\hline DPPH & $15 \mathrm{mcg} / \mathrm{ml}$ & $63.35 \mathrm{mcg} / \mathrm{ml}$ \\
\hline NO & $18 \mathrm{mcg} / \mathrm{ml}$ & $8.80 \mathrm{mcg} / \mathrm{ml}$ \\
\hline
\end{tabular}

LPO-Lipid peroxidation, DPPH-1-Diphenyl-2-picrylhydrazil, NO-Nitric oxide, IC-Inhibitory concentration

The DPPH scavenging activity by Alpinia galanga and Vit $\mathrm{E}$ is $63.35 \mathrm{mcg} / \mathrm{ml}$ and $15 \mathrm{mcg} / \mathrm{ml}$ respectively. The Nitric oxide free radical scavenging activity by Alpinia galanga and Vit E is $8.80 \mathrm{mcg} / \mathrm{ml}$ and $18 \mathrm{mcg} / \mathrm{ml}$ respectively (Table 1$)$.

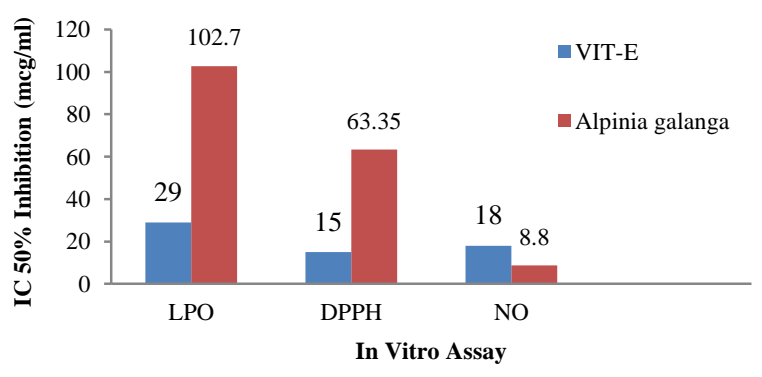

Figure 1: Comparison of Vitamin $\mathbf{E}$ and Alpinia galanga antioxidant activity.

\section{DISCUSSION}

The Alpinia galanga rhizome is used in traditional medicine for various degenerative diseases. ${ }^{12}$ The ethanolic extract of Alpinia galanga was subjected to acute toxicity study following OECD guidelines 423 
which was found to be safe and the data was published. ${ }^{13}$ The present study has attempted to find the antioxidant properties of Alpinia galanga in support to its beneficial effect in traditional medicine. In standardized in vitro Assay techniques by lipid peroxidation assay thiobarbituric acid reactive substance acts as marker to spectrophoto metric absorbance its estimation gives the extent of lipid peroxidation inhibition assay. ${ }^{9}$ The test group Alpinia galanga extract with $\mathrm{IC}_{50} 102.70 \mathrm{mcg} / \mathrm{ml}$ was not comparable to Vitamin $\mathrm{E} \mathrm{IC}_{50} 29.70 \mathrm{mcg} / \mathrm{ml}$, similarly the in vitro DPPH Alpinia galanga extract with $\mathrm{IC}_{50} 63.35 \mathrm{mcg} / \mathrm{ml}$ was not comparable with that of Vitamin $\mathrm{E}^{\mathrm{I}} \mathrm{IC}_{50} 15 \mathrm{mcg} / \mathrm{ml}$. The in vitro nitric oxide scavenging assay uses aqueous sodium nitroprusside which spontaneously generates nitric oxide at physiologic $\mathrm{pH}$ and the released NO interacts with oxygen to produce nitrite, which leads to colour change and the extent of inhibition is read from spectrophotometric absorbance 15 . The Alpinia galanga had significantly better $\mathrm{IC}_{50}$ of 8.80 $\mathrm{mcg} / \mathrm{ml}$ when compared to Vitamin $\mathrm{E} \mathrm{IC}_{50} 18 \mathrm{mcg} / \mathrm{ml}$. From Figure 1 it is clearly evident that the Alpinia galanga extract has superior activity in scavenging Nitric oxide free radical. Understanding oxidative damages involved in the pathophysiology of carcinogenesis and in particularly under inflammatory conditions endothelial cells macrophages and many more start expressing independent nitric oxide synthase. Nitric oxide is an physiological messenger and effector molecule in inflammation and immunity coupling with superoxides form peroxynitrite which in turn enhance synthesis of prostaglandins and thereby inflammation. ${ }^{15-18}$ Based on the better understanding of pathophysiology involved in inflammatory disease antioxidants with nitric oxide free radical scavenging activity, the present study has revealed the ability of Alpinia galanga extract in scavenging nitric oxide free radical.

\section{CONCLUSION}

Alpinia galanga ethanolic extract by in vitro assay has proven better nitric oxide free radical scavenging activity, this activity apart from its unexplored other positive effects on living organisms probably explain their use in traditional medicine. Further in vivo studies on the extract will provide us better understanding of traditional claims of Alpinia galanga as medicinal herb.

\section{Funding: No funding sources}

Conflict of interest: None declared

Ethical approval: The study was approved by the Institutional Ethics Committee

\section{REFERENCES}

1. Abdollahi M, Ranjbar A, Shadnia S, Nikfar S, Rezaiee A. Pesticides and oxidative stress: a review. Med Sci Monit. 2004;10:141-7.
2. Ames BN, Shigenega MK, Hagen TM. Oxidants and the degenerative diseases of ageing. Proc Nati Acad Sci. 1993;90:7915-22.

3. Shenoy R, Shirwaikar A. Anti-inflammatory and free radical scavenging studies of Hyptis suaveolens (labiatae). Indian drugs. 2002;39:574-7.

4. Patil S, Jolly CI, Narayanan S. Free radical scavenging activity of Acacia catechu and Rotula aquatica: implications in cancer therapy. Indian drugs. 2003;40:328-32.

5. Buyukokuroglu ME, Gulcin I, Oktay M, Kufrevioglu OI. In-vitro antioxidant properties of dantrolene sodium. Pharmacol Res. 2001;44:491-4.

6. Bergendi L, Benes L, Durackova Z, Ferencik M. Chemistry, physiology and pathology of free radicals. Life Sci. 1999;65:1865-74.

7. World Health Organisation. Traditional medicine. 2008. Available at http:// www.who.int/ mediacentre/factsheets /fs134/en/. Accessed on 23 April 2016.

8. Ohkawa H, Ohishi N, Yagi K. Assay of lipid peroxides in animal tissues by thio babituric acid reaction. Anal Biochem. 1979;95:346-51.

9. Sabina EP, Rasool M. Therapeutic efficacy of Indian ayurvedic herbal formulation triphala on lipid peroxidation, antioxidant status and inflammatory mediator TNF- $\alpha$ in adjuvant-induced arthritic mice. Int J Biol Chem. 2007;1:149-55.

10. Green LC, Wagner DA, Glogowski J, Skipper PL, Wishnok JS, Tannenbaum SR. Analysis of nitrate and in biological fluids. Anal Biochem. 1982;126:131.

11. Koleva II, Van Beek TA, Linssen JPH, De-Groot A, Evstatieva LN. Screening of plant extracts for antioxidant activity: a comparative study on three testing methods. Phytochemical Analysis. 2002;13:8-17.

12. Matsuda H. Gastroprotectjve effects of phenylpropanoids from the rhizomes of Alpinia galanga in rats: structural requirements and mode of action. European $\mathrm{J}$ Pharmacol. 2003;471:59-67.

13. Subash KR, Muthulakshmi Bhaarathi G, Cheriyan BV. Phytochemical screening and acute toxicity study of ethanolic extract of Alpinia galanga in rodents. Int J Med res Health Sci. 2012;2(1):93-100.

14. Al-Nimer MSM, Ali EA. Dual effects of interaction between meloxicam, diclofenac sodium or tramadol and nitrogen species radicals: In vitro comparative study. Int J Pharmacol. 2009;5:86-9.

15. Subapriya R, Kumaraguruparan R, ramahandran CR, Nagini S. Antioxidant status in patients with oral squamous cell carcinoma at different oral sites. Clin Biochem. 2002;35:489-93.

16. Medeiros MV, Binhara IM, Morena JH, Zatz R, De Nucci, Antunes E. Effect of chronic nitric oxide synthesis inhibition on the inflammatory responses induced by carrageenan in rats. Eur $\mathrm{J}$ Pharmacol. 1995;285:109-11. 
17. Sarkar D, Dutta A, Das M, Sarkar K, Mandal C, Chatterjee M. Effect of Aloe vera on nitric oxide production by macrophages during inflammation. Indian J Pharmacol. 2005;37:371-5.

18. Landino LM, Crews BC, Timmons MD, Morrow JD, Marnett LJ. Peroxynitrite the coupling product of nitric oxide and superoxide activates prostaglandin synthesis. Proc Natl Acad Sci USA. 1996;93:15069-74.

Cite this article as: Subash KR, Bhanu Prakash G. In-vitro anti-oxidant studies on ethanolic extract of Alpinia galanga linn. Int J Basic Clin Pharmacol 2016;5:1245-8. 